\title{
Biphenyl-4-yl-acrylohydroxamic acids: identification of a novel indolyl- substituted HDAC inhibitor with antitumor activity
}

Raffaella Cincinelli, ${ }^{ \pm a}$ Vincent Zwick ${ }^{ \pm b}$, Loana Musso $^{\mathrm{a}}$, Valentina Zuco ${ }^{\mathrm{c}}$, Michelandrea De Cesare ${ }^{\mathrm{c}}$, Franco Zunino $^{\mathrm{c}}$, Claudia Simoes-Pires ${ }^{\mathrm{b}}$, Alessandra Nurisso ${ }^{\mathrm{b}}$, Giuseppe Giannini ${ }^{\mathrm{d}}$, Muriel Cuendet $^{\mathrm{b}}$, Sabrina Dallavalle $\mathrm{a}^{*}$

a Department of Food, Environmental and Nutritional Sciences, Division of Chemistry and Molecular Biology, University of Milan, via Celoria 2, 20133 Milan, Italy.

${ }^{b}$ School of Pharmaceutical Sciences, University of Geneva, University of Lausanne, Quai ErnestAnsermet 30, 1211 Geneva 11, Switzerland.

${ }^{c}$ Fondazione IRCCS Istituto Nazionale Tumori, Via Amadeo 42, 20133 Milano, Italy.

${ }^{d}$ R\&D Sigma-Tau Industrie Farmaceutiche Riunite S.p.A., Via Pontina Km 30,400, I-00071 Pomezia, Roma, Italy.

${ }^{ \pm}$Equal contribution

\begin{abstract}
Modification of the cap group of biphenylacrylohydroxamic acid-based HDAC inhibitors led to the identification of a new derivative (3) characterized by an indolyl-substituted 4-phenylcinnamic skeleton. Molecular docking was used to predict the optimal conformation in the class I HDACs active site. Compound $\mathbf{3}$ showed HDAC inhibitory activity and antiproliferative activity against a panel of tumor cell lines, in the low $\mu \mathrm{M}$ range. The compound was further tested in vitro for acetylation of histone $\mathrm{H} 4$ and other non-histone proteins, and in vivo in a colon carcinoma model, showing significant proapoptotic and antitumor activities.
\end{abstract}

Keywords: Hydroxamic acids; HDAC inhibitors; antiproliferative activity; antitumor activity; synthesis. 


\section{Introduction}

Inappropriate epigenetic modifications of gene expression are associated with malignant phenotype and tumor progression. Regulation of gene expression is mediated by several mechanisms such as DNA methylation [1], ATP-dependent chromatin remodeling [2], and post-translational modifications of histones [3,4]. The latter mechanism includes dynamic acetylation and deacetylation of lysine amino residues present in the tail of core histones. Enzymes responsible for the reversible acetylation/deacetylation processes are histone acetyltransferases (HATs) and histone deacetylases (HDACs), respectively [5].

Being implicated in silencing of critical regulatory pathways, including proapoptotic programs, HDACs have recently gained prominence as an emerging class of anticancer targets [6].

Eighteen mammalian HDAC enzymes have been identified so far, which can be subdivided into four classes according to a cofactor $\left(\mathrm{Zn}^{2+}\right.$ for Classes I, II and IV or NAD ${ }^{+}$for Class III) [7].

A widely accepted pharmacophore model for HDAC inhibitors consists of a metal binding head group, a linker domain and a cap group, which interacts with the residues on the rim of the active site [7].

Recently, we have synthesized a series of hydroxamic acid-based compounds, characterized by a biphenyl-4-yl-acrylohydroxamic acid skeleton (compounds 1, Figure 1) [8]. The compounds were designed based on the hypothesis that the proximal phenyl ring, extended from the hydroxamic acid via a double bond, could be suitable to occupy the narrow tube-like pocket of the HDAC active site. In our model, the distal phenyl ring of $\mathbf{1}$ (cap moiety) appeared to be accommodated in a large cavity, without a significant steric clash. Indeed, crystal structures of HDAC enzymes show multiple grooves on the surface of the protein around the binding site and cap groups are in a position suitable to interact with these grooves [9]. Thus, modification of the cap group appeared the most promising strategy to optimize drug-target interactions.

On the basis of these findings, over the last few years we have conducted an extensive research on the cap modification of our compounds, with the aim to discover novel HDAC inhibitors with high potency and enhanced interactions within the HDACs active site [10,11].

The introduction of an oxime group on the cinnamic skeleton gave 4-oxime-cinnamoyl hydroxamates endowed with promising inhibitory activity on HDAC6 and HDAC8 coupled to a 
good selectivity profile [11]. Further attempts to modify the cap group with the incorporation of an adamantyl moiety led to a substantial reduction of inhibitory activity toward the tested enzymes [10].

In continuation of these efforts, we developed two new structures with modifications on the biphenyl system (compounds $\mathbf{2}$ and $\mathbf{3}$ ). Whereas in $\mathbf{2}$ we wanted to investigate the impact of the presence of a linker between the two rings on HDAC activity, in compound $\mathbf{3}$ an indole fragment was installed on the biphenyl system. The presence of this group has been recently associated with potent HDAC inhibition, mainly for nuclear HDACs 1 and 3 [12] and, differently from the adamantyl moiety, [10] could work as a versatile scaffold for further functionalization.

Here we show the HDAC inhibitory activity of the new compounds, both active in the low $\mu \mathrm{M}$ range. The synthesis and the evaluation of their biological activity are also reported.

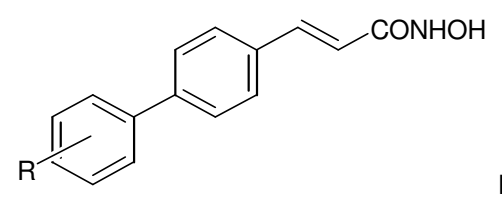

1<smiles>CC(C)=C(c1ccccc1)c1ccc(C=CC(=O)NO)cc1</smiles>

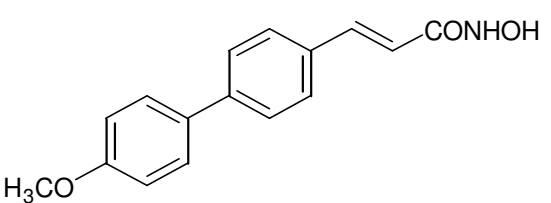

$1 \mathrm{a}$

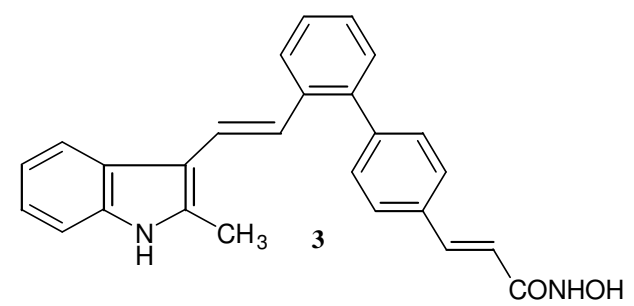

Fig.1. Structures of phenylacrylohydroxamic acids

\section{Results and discussion}

\subsection{Chemistry}

The synthesis of compound $\mathbf{2}$ started from the condensation of 4-bromobenzophenone $\mathbf{4}$ with acetone under McMurry conditions [13] to obtain 1-bromo-4-(2-methyl-1-phenylprop-1enyl)benzene (5). Heck coupling with methyl acrylate afforded 6 in $40 \%$ yield. Treatment of the ester 6 with $O$-tetrahydropyranylhydroxylamine gave 7, which was converted into the desired hydroxamic acid 2 by reaction with $p$-toluenesulfonic acid in methanol (Scheme 1).

Compound $\mathbf{3}$ was synthesized starting from the N-Boc-protected 3-formyl-2-methylindole $\mathbf{8}$, which was reacted with (2-bromobenzyl)triphenylphosphonium bromide 9 to give compound 10. Suzuki coupling with 4-formylphenylboronic acid afforded the aldehyde 11. Wittig reaction, followed by 
removal of the Boc protecting group and ester hydrolysis gave 14. Treatment of the acid with hydroxylamine hydrochloride afforded the hydroxamic acid $\mathbf{3}$ (Scheme 2).<smiles>COC(=O)/C=C/c1ccc(C(=C(C)C)c2ccccc2)cc1</smiles><smiles>CC(C)=C(c1ccccc1)c1ccc(/C=C/C(=O)NOC2CCCCO2)cc1</smiles>

Scheme 1. Synthesis of compound 2. Reagents and conditions: a) acetone, $\mathrm{TiCl}_{4}, \mathrm{Zn}$, dry THF, reflux, $2.5 \mathrm{~h}$, $71 \%$; b) methylacrylate, $\mathrm{Pd}\left(\mathrm{CH}_{3} \mathrm{COO}\right)_{2}$, tri(o-tolyl)phosphine, triethylamine, reflux, $3 \mathrm{~h}, 40 \%$; c) Otetrahydropyranylhydroxylamine, lithium hexamethyldisilazane, THF, rt, $1 \mathrm{~h}, 100 \%$; (d) p-toluenesulfonic acid monohydrate, $\mathrm{CH}_{3} \mathrm{OH}$, rt, overnight, $55 \%$.<smiles>Cc1c(/C=C/c2ccccc2C(C)(C)C)c2ccccc2n1C(=O)c1ccccc1</smiles><smiles>CCOC(=O)C=Cc1ccc(-c2ccccc2C=Cc2c(C)[nH]c3ccccc23)cc1</smiles><smiles>Cc1[nH]c2ccccc2c1/C=C/c1ccccc1-c1ccc(/C=C/C(=O)O)cc1</smiles><smiles>Cc1[nH]c2ccccc2c1/C=C/c1ccccc1-c1ccc(/C=C/C(=O)O)cc1</smiles>

Scheme 2. Synthesis of compound 3. Reagents and conditions: a) EtONa, ethanol, rt, $1 \mathrm{~h}, 31 \%$; b) 4formylphenylboronic acid, $\mathrm{Pd}\left(\mathrm{PPh}_{3}\right)_{4}, \mathrm{Na}_{2} \mathrm{CO}_{3} 2 \mathrm{M}$, toluene, reflux, $10 \mathrm{~h}, 87 \%$; c) $\mathrm{Ph} 33=\mathrm{P}=\mathrm{CHCOOEt}, \mathrm{CHCl}_{3}$, reflux, $8 \mathrm{~h}, 91 \%$; d) trifluoroacetic acid, $\mathrm{CH}_{2} \mathrm{Cl}_{2}, 0{ }^{\circ} \mathrm{C}, 2 \mathrm{~h}, 81 \%$; e) $\mathrm{LiOH} \cdot \mathrm{H}_{2} \mathrm{O}, \mathrm{THF} / \mathrm{H}_{2} \mathrm{O}$, rt, overnight, $94 \%$ f) hydroxylamine hydrochloride, N-(3-Dimethylaminopropyl)-N'-ethylcarbodiimide hydrochloride (WSC), 1-Hydroxybenzotriazole (HOBt), triethylamine, DMF, rt, 7 h, $97 \%$. 
2.2 HDAC inhibition, structural rationalization, and antiproliferative activity against human carcinoma cell lines

Compounds were first tested for their general HDAC inhibitory activity, by using a Hela nuclear extract as a source of HDACs. Compounds $\mathbf{2}$ and $\mathbf{3}$ showed a slightly better activity than 1a, a compoud we have previously tested for HDAC inhibition [8] (Table 1). It is important to notice that when HeLa cells were treated with each compound, a HDAC inhibition was found in the same range as observed in the enzymatic assay. Compound $\mathbf{3}$ was the most active towards nuclear HDACs when compared to compound $\mathbf{1 a}$ and $\mathbf{2}$, probably due to the addition of the indole cap group [12].

Table 1. HDAC2 inhibitory activity of compounds $\mathbf{1 - 3}$

\begin{tabular}{cccc}
\hline Compounds & $\begin{array}{c}\text { HeLa nuclear } \\
\text { extract }\end{array}$ & HDAC2 & HeLa cell \\
\hline & & $\mathrm{IC}_{50}[\mu \mathrm{M}]$ \\
\hline 1a & $32.6 \pm 3.7$ & $1.2 \pm 0.27^{\mathrm{a}}$ & $8.7 \pm 0.20$ \\
$\mathbf{2}$ & $2.6 \pm 0.38$ & $11.8 \pm 2.0$ & $2.5 \pm 0.18$ \\
$\mathbf{3}$ & $1.5 \pm 0.45$ & $5.2 \pm 0.13$ & $6.4 \pm 1.1$ \\
SAHA & $0.28 \pm 0.04$ & $0.10 \pm 0.02$ & -
\end{tabular}

Results are the mean \pm SD of three independent experiments.

${ }^{a}$ Ref. 8

A binding mode was proposed for compounds 2 and 3: docking studies were carried out on HDAC2 catalytic site (Figure 2). The molecular docking protocol was first validated through the re-docking of the co-crystallized SAHA within the HDAC2 protein structure. Docking calculations revealed the capability of the docking tool to retrieve the correct binding mode within HDAC2 [14]. For compound 2 (61\% convergent docking poses, best ranked pose: 77.4 ChemPLP score), a chelation of the zinc ion through the hydroxamate group was observed, as expected. The zinc binding portion of the molecule was further stabilized by polar contacts with Tyr308. Pi-pi stacking and van der Waals interactions with Phe155, Phe210, and Leu276 side chains, respectively, were also involved in the stabilization of the first phenyl ring of the linker portion, whereas the second ring was solvent exposed (Figure 2A). For compound 3 (Figure 2B, 60\% convergent docking poses, best ranked pose: 89.7 ChemPLP score) the interaction network between the hydroxamate, the aromatic linker, and the protein was conserved just as for compound 2. However, the indole group of compound $\mathbf{3}$, characterizing the cap portion of the molecule, was further stabilized by hydrophobic interactions with Pro34, Phe155, and Leu276 side chains, thus increasing complex stability (Figure 2B). 


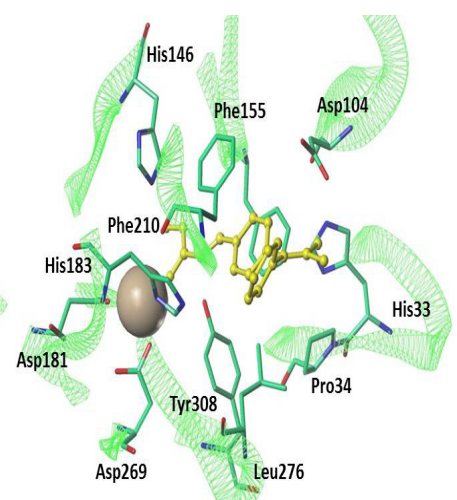

A

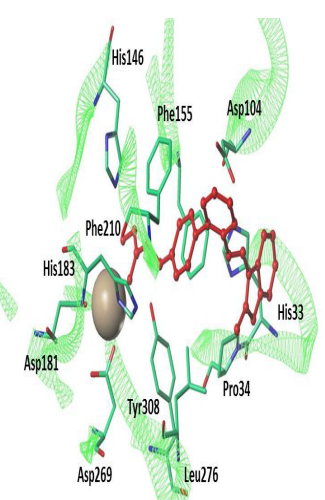

B

Fig. 2. HDAC2 in complex with compound 2 (best-ranked pose, yellow balls \& sticks, A), and compound 3 (best-ranked pose, red balls \& sticks, B). The protein is reported as green ribbons. Zinc ion is indicated as a gray ball. Residues involved in ligands stabilization are labeled.

Compounds $\mathbf{2}$ and $\mathbf{3}$ were then tested for their antiproliferative activity against a panel of tumor cell lines of different tissue origin. Derivative $\mathbf{3}$ appeared to be the most promising compound when tested against human ovarian carcinoma IGROV1, human lung carcinoma H460, human colon cancer cells HCT116 and human colon adenocarcinoma HT29 cell lines, exhibiting IC $_{50}$ values in the range of $0.3-1.4 \mu \mathrm{M}$. The antiproliferative activity on these cell lines is comparable or slightly better than the activity of the parent compound 1a and SAHA, a clinically approved pan-HDAC inhibitor (Table 2). Compound $\mathbf{3}$ was also tested on multidrug-resistant tumor cell lines: the subline of human colon adenocarcinoma cell line LoVo resistant to doxorubicin LoVo /DX, which expresses high levels of the P-glycoprotein; the subline of human colon adenocarcinoma cells HT29 resistant to mitoxantrone HT29/MIT, which exhibited a high up-regulation of the breast carcinoma resistance protein BCRP. The compound exhibited antiproliferative effects against resistant sublines with $\mathrm{IC}_{50}$ values similar to those obtained in corresponding sensitive cell lines.

Table 2. Antiproliferative activity $\left(\mathrm{IC}_{50}, \mu \mathrm{M}\right)$ of compounds 1a, $\mathbf{2 ,} 3$ and reference HDAC inhibitor (SAHA) against a panel of tumor cell lines.

\begin{tabular}{lccccccc}
\hline & IGROV-1 & H460 & LoVo & LoVo/DX & HT29 & HT29/MIT & HCT116 \\
\cline { 2 - 7 } Cpd & \multicolumn{7}{c}{$\mathrm{IC}_{50}(\mu \mathrm{M})$} \\
\hline 1a & $0.75 \pm 0.40$ & $3.7 \pm 0.1$ & $\mathrm{ND}$ & $\mathrm{ND}$ & $1.58 \pm 0.02$ & $1.73 \pm 0.11$ & $0.26 \pm 0.03$ \\
$\mathbf{2}$ & $2.5 \pm 1.09$ & $5.5 \pm 0.04$ & $2.79 \pm 0.59$ & $\mathrm{ND}$ & $4.12 \pm 0.08$ & $\mathrm{ND}$ & $2.00 \pm 0.57$ \\
$\mathbf{3}$ & $0.35 \pm 0.06$ & $1.41 \pm 0.09$ & $6.57 \pm 0.78$ & $4.62 \pm 0.03$ & $1.37 \pm 0.76$ & $2.44 \pm 0.34$ & $0.27 \pm 0.07$ \\
SAHA & $2.2 \pm 0.3$ & $3.4 \pm 0.8$ & $3.7 \pm 0.5$ & $\mathrm{ND}$ & $\mathrm{ND}$ & $\mathrm{ND}$ & $0.31 \pm 0.02$ \\
\hline
\end{tabular}

Results are the mean \pm SD of three independent experiments.

N.D.: not determined.

$\mathrm{IC}_{50}$ is defined as the drug concentration causing a 50\% reduction of cell number compared with that of untreated sample. 
Based on the enzymatic, structural, and antiproliferative results, compound $\mathbf{3}$ was chosen for further investigation. Protein acetylation, after 4 or 24 h of exposure to compound 3 and LAQ824, a panHDAC inhibitor used as reference compound, was investigated in the ovarian carcinoma cells IGROV-1, one of the most sensitive cell lines in our panel (Figure 3). As expected, LAQ824 induced a marked acetylation of histone H4, p53 and tubulin. Interestingly, under the same conditions, treatment with compound $\mathbf{3}$ increased the levels of acetylated tubulin. Since this effect is usually consistent with cytoplasmic HDAC6 isoform selectivity, a comparative study on the effects on different HDAC isoforms was also carried out (Table 3).

Table 3. Inhibition of HDAC isoforms by compound $\mathbf{3}^{\text {a }}$.

\begin{tabular}{|c|c|c|c|c|c|c|c|c|c|c|}
\hline & HDAC-1 & HDAC-3 & HDAC-4 & HDAC-5 & HDAC-6 & HDAC- 7 & HDAC-8 & HDAC-9 & HDAC-10 & HDAC-11 \\
\hline \multicolumn{11}{|c|}{$\mathrm{IC}_{50}(\mu \mathrm{M})$} \\
\hline SAHA & 0.26 & 0.35 & 0.49 & 0.38 & 0.029 & 0.034 & 0.24 & 0.32 & 0.46 & 0.36 \\
\hline 3 & 5.4 & 3.9 & 17.1 & 8.0 & 1.0 & 10.9 & 0.58 & 8.9 & 10.2 & 16.2 \\
\hline
\end{tabular}

According to Table 3, compound 3 can be considered as a pan-HDAC inhibitor for its capacity to inhibit all of the HDACs isoforms, with a preferential inhibition towards HDAC6 together with HDAC8.

The inhibition of HDAC8 could be pharmacologically relevant, because this isoform is deregulated and overexpressed in tumor cells. Moreover, HDAC8 is known to interact with various transcription factors, including p53, and therefore implicated in modulation of apoptosis [15]

Induction of apoptosis was thus examined for compound 3 following $72 \mathrm{~h}$ exposure (Figure 4).

Compound 3 triggered apoptotic processes in IGROV-1 cells with the appearance of around 34\% and $79 \%$ TUNEL-positive cells at $\mathrm{IC}_{50}$ and $\mathrm{IC}_{80}$, respectively. Interestingly, the compound was more effective as apoptosis inducer than SAHA under the same conditions (79\% vs $37 \%$ at equitoxic concentrations, $\left.\mathrm{IC}_{80}\right)[10]$.

The marked cell death response to the treatment was also consistent with the presence of a large sub-G1 peak (Figure 4). Moreover, the exposure of this compound strongly promoted cell cycle arrest primarily at the G1 phase (Figure 4). The potent proapoptotic activity of $\mathbf{3}$ could be consistent with HDAC8 inhibition.

The in vivo antitumor activity of $\mathbf{3}$ was examined in the colon carcinoma xenograft HCT116. A daily oral administration ( 5 days/week) for 4 weeks produced a significant tumor growth inhibition $(68 \%, p<0.01$, Figure 5). The antitumor efficacy of $\mathbf{3}$ was more persistent than SAHA (48\% tumor growth inhibition) as indicated by the tumor growth delay following the end of treatment. The 
antitumor efficacy is consistent with the expected responsiveness of the tumor model (HCT116) to HDAC inhibitors. However, we cannot rule out other off-target effects.

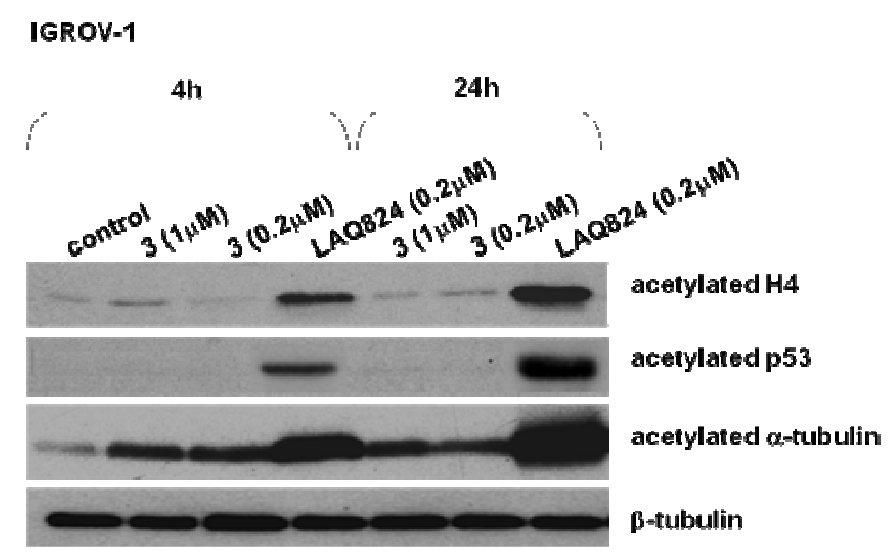

Fig. 3. Effects of compound 3 and LAQ824 (reference compound) on acetylation of tubulin, histone H4 and p53 in IGROV-1 cells. Cells were treated for $24 \mathrm{~h}$ with equitoxic $(1 \mu \mathrm{M}$ compound 3 and $0.2 \mu \mathrm{M}$ LAQ824, corresponding to $\mathrm{IC}_{80}$ value) and equimolar concentration values $(0.2 \mu \mathrm{M})$. Cell lysates were prepared and examined by western-blot analysis. The blots were reprobed with $\beta$-tubulin as a loading control.
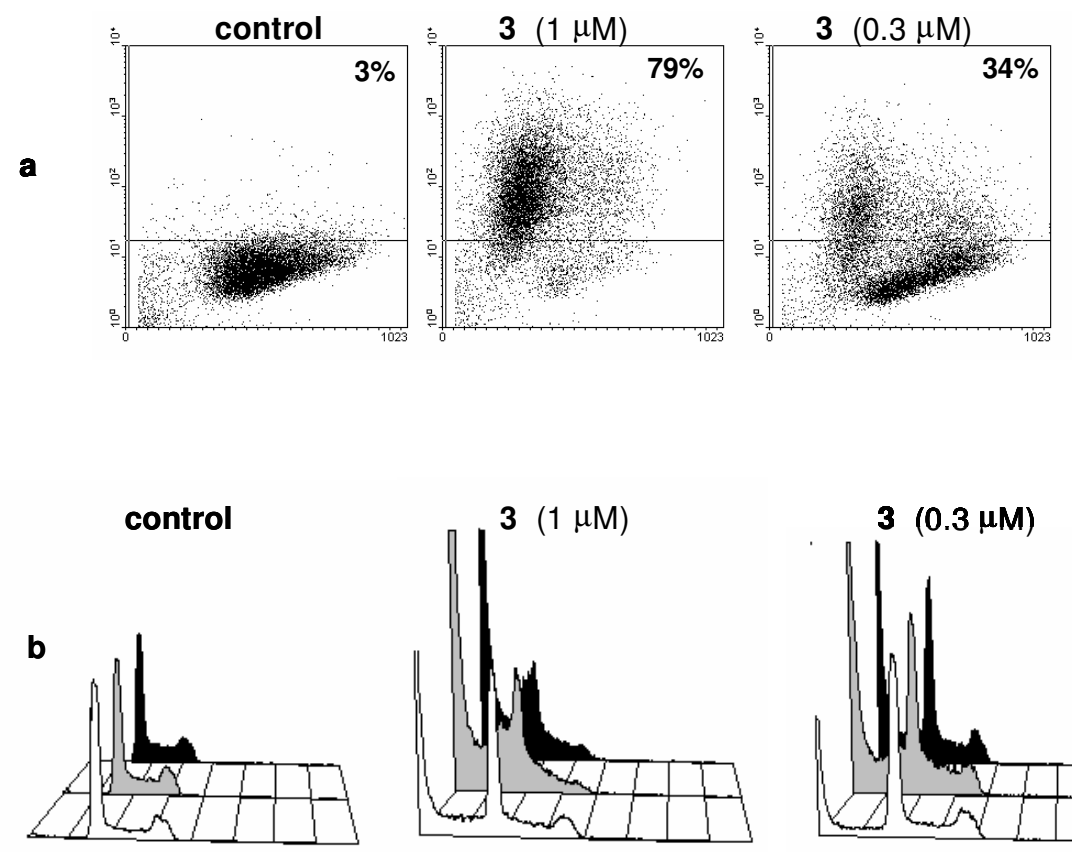

G1 G2
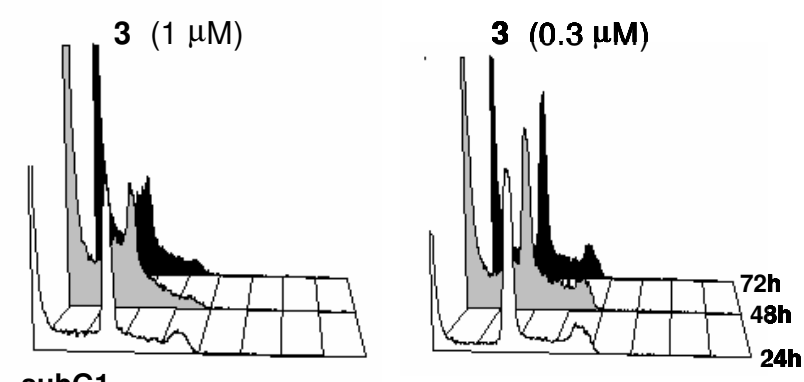

Fig. 4. Flow cytometric analysis of apoptosis and cell cycle perturbation induced after the exposure to compound 3 ( $\mathrm{IC}_{80}$ and $\mathrm{IC}_{50}$ value) in ovarian carcinoma cells IGROV-1. a) The extent of apoptosis was determined $72 \mathrm{~h}$ after drug exposure by TUNEL assay. b) Time course analysis of cell cycle was performed by propidium-iodide staining. 


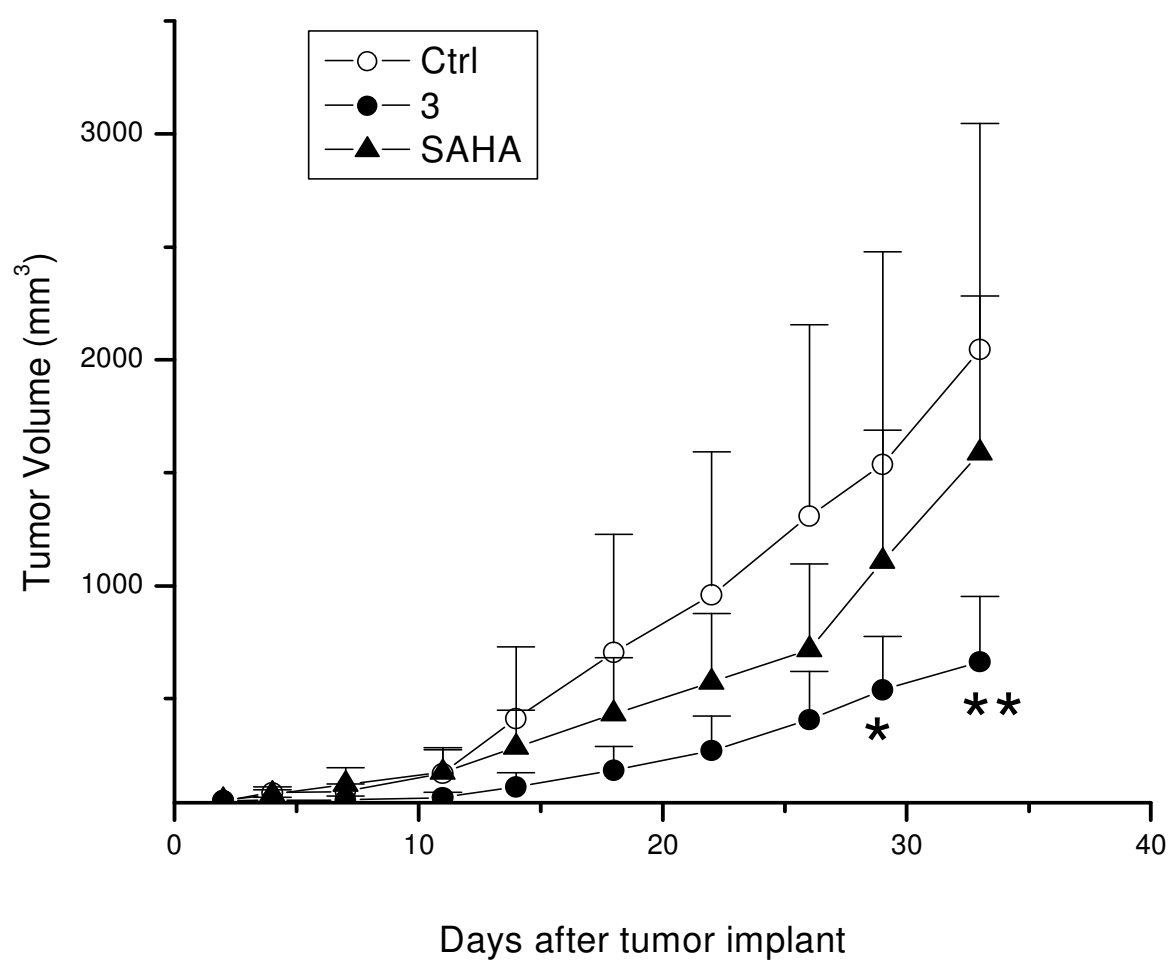

Fig. 5. Antitumor effect of compound $\mathbf{3}$ and SAHA against the human colon carcinoma HCT116. Animals were treated with once daily administration for 5 days a week for 4 weeks by oral route with $175 \mathrm{mg} / \mathrm{kg}$. Control refers to animals treated with solvent only.

\section{Conclusions}

In an effort to improve the pattern of HDAC inhibitory activity of biphenyl-4-yl-acrylohydroxamic acids, we have identified two new structures with branching points in the biphenyl system. The best candidate, 3, showed HDAC inhibition and antiproliferative activity on a panel of tumor cell lines in the low $\mu \mathrm{M}$ range. The compound was further tested in vitro for acetylation of $\mathrm{H} 4$ histone and other target proteins, and in vivo in a colon carcinoma model, showing promising proapoptotic and antitumor activities.

Due to its in vitro as well as in vivo activity profile, compound $\mathbf{3}$ represents an interesting starting point for the design of next generation HDAC inhibitors. Docking studies of compounds $\mathbf{3}$ and $\mathbf{1 a}$ in HDAC2 catalytic site, showed that the indole moiety gave additional hydrophobic interactions with the aminoacids in the pocket, thus increasing the complex stability. Functionalization of this more versatile scaffold could provide further favourable interactions with the perspective of enhancing target inhibition and pharmacological efficacy.

\section{Experimental section}

\subsection{Chemistry}


All reagents and solvents were reagent grade or were purified by standard methods before use. Melting points were determined in open capillaries and are uncorrected. NMR spectra were recorded in $\mathrm{CDCl}_{3}$ (where not otherwise stated) at $300 \mathrm{MHz}$. Chemical shifts ( $\delta$ values) and coupling constants ( $\mathrm{J}$ values) are given in $\mathrm{ppm}$ and $\mathrm{Hz}$, respectively. Solvents were routinely distilled prior to use; anhydrous tetrahydrofuran (THF) and ether $\left(\mathrm{Et}_{2} \mathrm{O}\right)$ were obtained by distillation from sodium-benzophenone ketyl; dry methylene chloride was obtained by distillation from phosphorus pentoxide. All reactions requiring anhydrous conditions were performed under a positive nitrogen flow, and all glassware were oven dried and/or flame dried. Isolation and purification of the compounds were performed by flash column chromatography on silica gel 60 (230-400 mesh). Analytical thin-layer chromatography (TLC) was conducted on Fluka TLC plates (silica gel $60 \mathrm{~F}_{254}$, aluminum foil).

\subsection{1-Bromo-4-(2-methyl-1-phenyl-1-propen-1-yl)-benzene (5).}

$\mathrm{TiCl}_{4}(1.66 \mathrm{~mL}, 15.3 \mathrm{mmol})$ was added to a stirred suspension of zinc powder $(1.99 \mathrm{~g}, 30.6 \mathrm{mmol})$ in dry THF $(34 \mathrm{~mL})$, under nitrogen, at $-10^{\circ} \mathrm{C}$. When the addition was complete, the mixture was warmed to room temperature and then refluxed for $2 \mathrm{~h}$. To the cooled suspension of the titanium reagent was added a solution of 4-bromobenzophenone $(1.00 \mathrm{~g}, 3.82 \mathrm{mmol})$ and acetone $(0.33 \mathrm{~g}$, $0.84 \mathrm{~mL}, 11.46 \mathrm{mmol})$ in dry $\mathrm{THF}(70 \mathrm{~mL})$ at $0{ }^{\circ} \mathrm{C}$, and the mixture was refluxed in the dark for 2.5 $\mathrm{h}$, then it was stirred overnight at room temperature. The reaction mixture was poured into $10 \%$ aqueous potassium carbonate and extracted with EtOAc. The organic layer was washed with brine, dried $\left(\mathrm{Na}_{2} \mathrm{SO}_{4}\right)$, and concentrated in vacuo. Flash column chromatography (hexane/ethyl acetate 8:2) afforded 5 as a colorless oil. Yield 71\%. ${ }^{1} \mathrm{H}$ NMR $\left(\mathrm{CDCl}_{3}\right) \delta: 7.39(\mathrm{~d}, 2 \mathrm{H}, J=8.3 \mathrm{~Hz}), 7.32$ $7.10(\mathrm{~m}, 4 \mathrm{H}), 7.00(\mathrm{~d}, 1 \mathrm{H}, J=8.3 \mathrm{~Hz}), 1.81(\mathrm{~s}, 6 \mathrm{H})$. Anal. calcd for $\mathrm{C}_{16} \mathrm{H}_{15} \mathrm{Br}$ : C, 66.91; H, 5.26. Found: C, 66.99; H, 5.24.

\subsection{3-[4-(2-Methyl-1-phenyl-propenyl)-phenyl]-acrylic acid methyl ester (6).}

A mixture of 5 (267 mg, $0.93 \mathrm{mmol})$, acrylic acid methyl ester (127 mg, $1.48 \mathrm{mmol})$, Pd(II) acetate (2 mg, $0.009 \mathrm{mmol})$, tri $(o$-tolyl)phosphine $(11 \mathrm{mg}, 0.037 \mathrm{mmol})$ and triethylamine $(539 \mathrm{mg}, 5.33$ mmol) were refluxed for $3 \mathrm{~h}$. After cooling to room temperature, the solution was poured into water, acidified with $3 \mathrm{~N} \mathrm{HCl}$ and extracted with ethyl acetate. The organic phase was dried over $\mathrm{Na}_{2} \mathrm{SO}_{4}$ and evaporated under reduced pressure. The crude product was purified by flash chromatography (hexane/ethyl acetate 9:1) to give $110 \mathrm{mg}$ of the title compound as an oil. Yield $40 \% .{ }^{1} \mathrm{H}$ NMR $\left(\mathrm{CDCl}_{3}\right) \delta: 7.68(\mathrm{~d}, 1 \mathrm{H}, J=15.8 \mathrm{~Hz}), 7.43(\mathrm{~d}, 2 \mathrm{H}, J=8.3 \mathrm{~Hz}), 7.35-7.00(\mathrm{~m}, 7 \mathrm{H}), 6.80(\mathrm{~d}, 1 \mathrm{H}, J=$ 
$15.8 \mathrm{~Hz}), 3.80(\mathrm{~s}, 3 \mathrm{H}), 1.85(\mathrm{~s}, 3 \mathrm{H}), 1.81(\mathrm{~s}, 3 \mathrm{H})$. Anal. calcd for $\mathrm{C}_{20} \mathrm{H}_{20} \mathrm{O}_{2}: \mathrm{C}, 82.16 ; \mathrm{H}, 6.89$. Found: C, 82.39; H, 6.87.

\subsection{3-[4-(2-Methyl-1-phenyl-propenyl)-phenyl]-N-(tetrahydropyran-2-yloxy)-acrylamide (7).}

Compound $6(110 \mathrm{mg}, 0.37 \mathrm{mmol})$, was dissolved in $5 \mathrm{~mL}$ of anhydrous $\mathrm{THF}$, then Otetrahydropyranylhydroxylamine $(43 \mathrm{mg}, 0.37 \mathrm{mmol})$ was added. The solution was cooled to $-78{ }^{\circ} \mathrm{C}$ and treated with $0.75 \mathrm{~mL}(0.77 \mathrm{mmol})$ of lithium hexamethyldisilazane. The mixture was stirred for $1 \mathrm{~h}$ under nitrogen, then was quenched with $\mathrm{NH}_{4} \mathrm{Cl}$ solution. Once at room temperature, the mixture was extracted with ethyl acetate and the organic phase was dried over $\mathrm{Na}_{2} \mathrm{SO}_{4}$. The solvent was evaporated under reduced pressure to give $139 \mathrm{mg}$ of the desired compound as an pale yellow oil. Yield 100\%. ${ }^{1} \mathrm{H}$ NMR $\left(\mathrm{CDCl}_{3}\right) \delta: 8.36(\mathrm{~s}, 1 \mathrm{H}), 7.71(\mathrm{~d}, 1 \mathrm{H}, J=15.7 \mathrm{~Hz}), 7.46(\mathrm{~d}, 2 \mathrm{H}, J=8.3$ $\mathrm{Hz}), 7.36-7.00(\mathrm{~m}, 8 \mathrm{H}), 6.37$ (brs, 1H), 5.13-4.88 (m, 1H), 4.05-3.85 (m, 1H), 3.77-3.55 (m, 1H), $1.82(\mathrm{~s}, 3 \mathrm{H}), 1.76(\mathrm{~s}, 3 \mathrm{H}), 1.71-1.46(\mathrm{~m}, 6 \mathrm{H})$. Anal. calcd for $\mathrm{C}_{24} \mathrm{H}_{27} \mathrm{NO}_{3}$ : C, 76.36; H, 7.21; N, 3.71. Found: C, 76.21; H, 7.19; N, 3.72.

\subsection{N-Hydroxy-3-[4-(2-methyl-1-phenyl-propenyl)-phenyl]-acrylamide (2).}

Compound 7 (60 mg, $0.17 \mathrm{mmol}$ ) was dissolved in $1.8 \mathrm{~mL}$ of methanol, then p-toluenesulfonic acid monohydrate $(9 \mathrm{mg}, 0.005 \mathrm{mmol})$ was added. The mixture was stirred overnight at room temperature. The solvent was concentrated and the solid formed was filtered and washed with water to afford $27 \mathrm{mg}$ of the title compound as a white solid. Yield 55\%, M.p. $186-187^{\circ} \mathrm{C}$. ${ }^{1} \mathrm{H}$ NMR (DMSO-d $)$ ): 10.78 (s, 1H), 9.05 (brs, 1H), 7.57-7.38 (m, 3H), 7.36-7.20 (m, 3H), 7.17-7.05 (m, $4 \mathrm{H}), 7.42(\mathrm{~d}, 1 \mathrm{H}, J=15.7 \mathrm{~Hz})$.

${ }^{13} \mathrm{C}$ NMR (DMSO-d 6 ) $\delta: 163.2,144.4,142.9,138.5,136.6,133.2,131.6,130.4,129.9(\times 2), 128.5$ (× 2), 127.7, 126.8, 119.1, 22.7, 22.6. Anal. calcd for $\mathrm{C}_{19} \mathrm{H}_{19} \mathrm{NO}_{2}: \mathrm{C}, 77.79 ; \mathrm{H}, 6.53 ; \mathrm{N}, 4.77$. Found: C, 77.57; H, 6.55; N, 4.79 .

\section{6. (E)-3-[2-(2-Bromo-phenyl)-vinyl]-1-tert-butyloxycarbonyl-2-methyl-indole (10).}

To a solution of EtONa (1.2 g, $18.33 \mathrm{mmol})$ in ethanol $(54 \mathrm{~mL})$, (2bromobenzyl)triphenylphosphonium bromide [16] (9.79 g, $19.13 \mathrm{mmol})$ was slowly added and the mixture was stirred at room temperature for $3 \mathrm{~h}$. After cooling at $0{ }^{\circ} \mathrm{C}, 3$-formyl-2-methyl-indole-1carboxylic acid tert-butyl ester [117] (4 g, $15.43 \mathrm{mmol})$ was added portionwise and the stirring was continued for $1 \mathrm{~h}$ at room temperature. The solution was poured into $1 \mathrm{~N} \mathrm{HCl}$ and extracted with diethyl ether $(\times 3)$. The organic phase was washed with brine, dried over $\mathrm{Na}_{2} \mathrm{SO}_{4}$ and evaporated under reduced pressure. The residue was purified by crystallization from ethyl ether/hexane to 
afford $1.96 \mathrm{~g}$ of the desired compound as a white solid. Yield 31\%. ${ }^{1} \mathrm{H}$ NMR (DMSO- $\left.\mathrm{d}_{6}\right) \delta$ : 8.19$8.10(\mathrm{~m}, 1 \mathrm{H}), 8.06-7.89(\mathrm{~m}, 2 \mathrm{H}), 7.68(\mathrm{~d}, 1 \mathrm{H}, J=8.49 \mathrm{~Hz}), 7.52-7.31(\mathrm{~m}, 5 \mathrm{H}), 7.22(\mathrm{t}, 1 \mathrm{H}, J=7.25$ $\mathrm{Hz}), 2.71$ (s, 3H), 1.67 (s, 9H). Anal. calcd for $\mathrm{C}_{22} \mathrm{H}_{22} \mathrm{BrNO}_{2}$ : C, 64.09; H, 5.38; N, 3.40. Found: C, 64.28; H, 5.39; N, 3.38.

\section{7. (E)-3-[2-(4'-formyl-biphenyl-2-yl)-vinyl]- 1-tert-butyloxycarbonyl 2-methyl-indole- (11).}

Compound 10 (1.91 g, $4.68 \mathrm{mmol}$ ) was dissolved in toluene, then $2 \mathrm{M} \mathrm{Na}_{2} \mathrm{CO}_{3}(4.68 \mathrm{~mL}), \mathrm{Pd}_{\left(\mathrm{PPh}_{3}\right)_{4}}$ (162 mg, $0.140 \mathrm{mmol}$ ) and 4-formylphenylboronic acid (789 $\mathrm{mg}, 5.15 \mathrm{mmol}$ ) were added under nitrogen and the mixture was refluxed for $10 \mathrm{~h}$. After cooling to room temperature, ethyl acetate was added and the organic phase was washed with brine, dried over $\mathrm{Na}_{2} \mathrm{SO}_{4}$ and evaporated under reduced pressure. The crude product was purified by flash chromatography (hexane/ethyl acetate 90:10) to give $1.79 \mathrm{~g}$ of the title compound as a white solid. Yield $87 \%$. M.p. $102{ }^{\circ} \mathrm{C}$. ${ }^{1} \mathrm{H}$ NMR $\left(\mathrm{CDCl}_{3}\right) \delta: 10.15(\mathrm{~s}, 1 \mathrm{H}), 8.15(\mathrm{~d}, 1 \mathrm{H}, J=7.4 \mathrm{~Hz}), 7.98(\mathrm{~d}, 2 \mathrm{H}, J=8.20 \mathrm{~Hz}), 7.87(\mathrm{~d}, 1 \mathrm{H}, J=7.7$ $\mathrm{Hz}), 7.67(\mathrm{~d}, 2 \mathrm{H}, J=8.20 \mathrm{~Hz}), 7.59-7.38(\mathrm{~m}, 4 \mathrm{H}), 7.31-7.00(\mathrm{~m}, 4 \mathrm{H}), 2.69(\mathrm{~s}, 3 \mathrm{H}), 1.71(\mathrm{~s}, 9 \mathrm{H})$. Anal. calcd for $\mathrm{C}_{29} \mathrm{H}_{27} \mathrm{NO}_{3}$ : C, 79.61; H, 6.22; N, 3.20. Found: C, 79.88; H, 6.18; N, 3.18.

\section{8.(E,E)-3-\{2-[4'-(2-ethoxycarbonyl-vinyl)-biphenyl-2-yl]-vinyl\}-1-tert-butyloxycarbonyl methylindole (12).}

Compound 11 (1.74 g, $3.98 \mathrm{mmol}$ ) was dissolved in chloroform (21 mL) under nitrogen, then (carbethoxymethylidene)triphenylphosphorane $(1.39 \mathrm{~g}, 3.98 \mathrm{mmol})$ was added and the mixture was refluxed for $8 \mathrm{~h}$. The solvent was evaporated and the residue was purified by flash chromatography (hexane/diethyl ether 90:10) to give $1.82 \mathrm{~g}$ of the title compound as a yellow solid. Yield 91\%. M.p. 62-63 ${ }^{\circ} \mathrm{C} .{ }^{1} \mathrm{H}$ NMR $\left(\mathrm{CDCl}_{3}\right) \delta: 8.14(\mathrm{~d}, 1 \mathrm{H}, J=7.4 \mathrm{~Hz}), 7.89-7.70(\mathrm{~m}, 2 \mathrm{H}), 7.61(\mathrm{~d}, 2 \mathrm{H}, J=8.20$ $\mathrm{Hz}), 7.58-7.35(\mathrm{~m}, 7 \mathrm{H}), 7.31-7.08(\mathrm{~m}, 3 \mathrm{H}), 6.50(\mathrm{~d}, 1 \mathrm{H}, J=16.50 \mathrm{~Hz}), 4.30(\mathrm{q}, 2 \mathrm{H}, J=7.1 \mathrm{~Hz})$, $2.68(\mathrm{~s}, 3 \mathrm{H}), 1.71(\mathrm{~s}, 9 \mathrm{H}), 1.39(\mathrm{t}, 3 \mathrm{H}, J=7.1 \mathrm{~Hz})$. Anal. calcd for $\mathrm{C}_{33} \mathrm{H}_{33} \mathrm{NO}_{4}: \mathrm{C}, 78.08 ; \mathrm{H}, 6.55 ; \mathrm{N}$, 2.76. Found: C, 78.18; H, 6.57; N, 2.74.

\section{9. (E,E)-3-\{2'-[2-(2-methyl-1H-indol-3-yl)-vinyl]-biphenyl-4-yl\}-acrylic acid ethyl ester (13).}

Compound 12 (1.61 g, $3.18 \mathrm{mmol})$ was dissolved in dry dichloromethane $(31.8 \mathrm{~mL})$ and the solution was cooled to $0{ }^{\circ} \mathrm{C}$. Trifluoroacetic acid $(31.8 \mathrm{~mL})$ was slowly dropped and the mixture was stirred at $0{ }^{\circ} \mathrm{C}$ for $2 \mathrm{~h}$. The solvent was evaporated under reduce pressure, the residue was diluted with diethyl ether and washed with sodium bicarbonate. The organic phase was dried over $\mathrm{Na}_{2} \mathrm{SO}_{4}$, filtered and evaporated under reduced pressure. The crude product was purified by flash chromatography (hexane/acetone 70:20) to afford $1.05 \mathrm{~g}$ of the desired compound. Yield 81\%. M.p. 
$110{ }^{\circ} \mathrm{C} .{ }^{1} \mathrm{H}$ NMR $\left(\mathrm{CDCl}_{3}\right) \delta: 7.98(\mathrm{~s}, 1 \mathrm{H}), 7.87-7.72(\mathrm{~m}, 2 \mathrm{H}), 7.68-7.49(\mathrm{~m}, 5 \mathrm{H}), 7.48-7.20(\mathrm{~m}, 3 \mathrm{H})$, 7.18-6.98 (m, 3H), $6.50(\mathrm{~d}, 1 \mathrm{H}, J=16.50 \mathrm{~Hz}), 4.31(\mathrm{q}, 2 \mathrm{H}, J=7.1 \mathrm{~Hz}), 2.51(\mathrm{~s}, 3 \mathrm{H}), 1.39$ (t, 3H, $J$ $=7.1 \mathrm{~Hz}$ ). Anal. calcd for $\mathrm{C}_{28} \mathrm{H}_{25} \mathrm{NO}_{2}: \mathrm{C}, 82.53 ; \mathrm{H}, 6.18 ; \mathrm{N}, 3.44$. Found: C, 82.40; H, 6.20; N, 3.43 .

\subsection{0. (E,E)-3-\{2'-[2-(2-methyl-1H-indol-3-yl)-vinyl]-biphenyl-4-yl\}-acrylic acid (14)}

Compound 13 (2.15 g, $5.28 \mathrm{mmol})$ was dissolved in a solution of $1.1 \mathrm{~g}(26.4 \mathrm{mmol})$ of $\mathrm{LiOH} \cdot \mathrm{H}_{2} \mathrm{O}$ in $247 \mathrm{~mL}$ of $\mathrm{THF} / \mathrm{H}_{2} \mathrm{O}$ 1:1 and the mixture was stirred overnight at room temperature in the dark. THF was evaporated and the aqueous phase was acidified with $1 \mathrm{~N} \mathrm{HCl}$. The solid formed was filtered and dried to give $1.87 \mathrm{~g}$ of the desired compound as a yellow solid. Yield 94\%. M.p. 129$130{ }^{\circ} \mathrm{C} ;{ }^{1} \mathrm{H}-\mathrm{NMR}\left(300 \mathrm{MHz}, \mathrm{DMSO}_{\mathrm{d}}\right.$ ) $\delta: 12.45$ (brs, $\left.1 \mathrm{H}\right), 11.22$ (s, 1H), 7.91 (d, 1H, J= 7.4 Hz), $7.82(\mathrm{~d}, 2 \mathrm{H}, J=8.20 \mathrm{~Hz}), 7.69(\mathrm{~d}, 1 \mathrm{H}, J=16.50 \mathrm{~Hz}), 7.52-7.22(\mathrm{~m}, 8 \mathrm{H}), 7.08-6.82(\mathrm{~m}, 3 \mathrm{H}), 6.60$ (d, $1 \mathrm{H}, J=16.50 \mathrm{~Hz}), 2.43$ (s, 3H). Anal. calcd for $\mathrm{C}_{26} \mathrm{H}_{21} \mathrm{NO}_{2}$ : C, 82.30; H, 5.55; N, 3.67. Found: C, 82.50; H, 5.43; N, 3.44.

\subsection{1. (E,E)-N-Hydroxy-3-\{2'-[2-(2-methyl-1H-indol-3-yl)-vinyl]-biphenyl-4-yl\}-acrylamide (3).}

Compound 14 (1.86 g, $4.92 \mathrm{mmol}$ ) was dissolved in $56 \mathrm{~mL}$ of DMF, then 1-hydroxybenzotriazole (HOBt) (1.16 g, $7.38 \mathrm{mmol}$ ) was added in one portion followed by N-(3-Dimethylaminopropyl)-N'ethylcarbodiimide hydrochloride (WSC) $(1.54 \mathrm{~g}, 7.87 \mathrm{mmol})$ and the mixture was stirred at room temperature for $5 \mathrm{~h}$ in the dark. To the orange solution hydroxylamine hydrochloride $(1.7 \mathrm{~g}, 24.6$ mmol) and triethylamine $(3.41 \mathrm{~mL}, 24.6 \mathrm{mmol})$ were added and the stirring was continued for $2 \mathrm{~h}$. The suspension was diluted with water $(250 \mathrm{~mL})$, filtered and the solid was washed with water to afford $1.89 \mathrm{~g}$ of the desired compound as a yellow sticky solid. Yield 97\%. ${ }^{1} \mathrm{H}$ NMR (DMSO-d 6 ) $\delta$ : 11.25 (s, 1H), 10.81 (brs, 1H), 9.08 (brs, 1H), 7.91 (d, 1H, J = 7.4 Hz), 7.70 (d, 2H, J = 7.5 Hz), 7.63-7.21 (m, 9H), 7.15-6.75 (m, 3H), $6.55(\mathrm{~d}, 1 \mathrm{H}, J=16.50 \mathrm{~Hz}), 2.43$ (s, 3H). ${ }^{13} \mathrm{C}$ NMR (DMSO$\left.\mathrm{d}_{6}\right) \delta: 163.1,142.5,139.3,138.3,136.8(\times 2), 136.1,134.1,130.6(\times 2), 130.2,128.3,127.8(\times 2)$, 126.7, 126.2, 125.0, 123.7, 121.6, 121.3, 120.0, 119.6, 199.0, 111.5, 110.2, 12.2. Anal. calcd for $\mathrm{C}_{26} \mathrm{H}_{22} \mathrm{~N}_{2} \mathrm{O}_{2}$ : C, 79.16; H, 5.62; N, 7.10. Found: C, 79.04; H, 5.60; N, 7.08.

\subsection{Enzymatic assays}

Compounds were tested for HDAC inhibition on HeLa nuclear extract (Enzo Life Sciences, Lausen, Switzerland) and HDAC2 (Sigma-Aldrich, Buchs, Switzerland). Reactions were carried out in 96well $1 / 2$ volume microplates. The HeLa nuclear extract or specific isoform were diluted in assay buffer (50 mM Tris at pH 8.0 adjusted with $\mathrm{HCl}, 137 \mathrm{mM} \mathrm{NaCl}, 2.7 \mathrm{mM} \mathrm{KCl}, 1 \mathrm{mM} \mathrm{MgCl}_{2}$ ) and added to each microplate well, except for blanks. Test compounds were diluted in DMSO and 
added to $100 \mu \mathrm{M}$ (5\% DMSO in each well) for screening purposes. The reaction was initiated by the addition of BOC-Ac-Lys-AMC substrate for HeLa nuclear extract or the Fluor de Lys ${ }^{\mathrm{TM}}$ Green substrate (BML-KI572, Enzo) for HDAC2. The plate was then incubated at $37^{\circ} \mathrm{C}$ for 90 min (HeLa nuclear extract) or $30 \mathrm{~min}$ (HDAC2). The reaction was stopped with $1 \mu \mathrm{M}$ Trichostatin A. Trypsin from bovine pancreas, $7500 \mathrm{BAEE}$ units/mg (Sigma-Aldrich) was added $30 \mathrm{~min}$ prior to plate reading. HDAC inhibition was calculated by comparing the amount of deacetylated substrate between control (100\% HDAC activity) and test sample. The relative amount of deacetylated substrate was obtained by fluorescence reading with excitation at $360 \mathrm{~nm}$ and emission at $460 \mathrm{~nm}$ for HeLa nuclear extract. Excitation at $485 \mathrm{~nm}$ and emission at $528 \mathrm{~nm}$ were used for HDAC2. Dose-response curves were obtained with 6 different concentrations to determine the $\mathrm{IC}_{50}$ values of active compounds. Results are the mean of three independent experiments. Trichostatin A was used as positive control.

\subsection{Histone Deacetylase Profiling (HDAC1, HDAC3-11)}

HDAC profiling was performed by Reaction Biology Corp. (Malvern, PA) against 10 isolated isoforms of human HDAC (HDAC1, HDAC3-11) in the presence of the fluorogenic tetrapeptide RHKKAc (p53 residues 379-382) as the substrate $(50 \mu \mathrm{M})$. Isolated human HDACs were obtained by standard purification, with the exception of HDAC3, which was isolated in complex with NCOR2 and used as such. SAHA was used as reference compound. Each compound was dissolved in DMSO (1:3 diluition; 10 doses), and sequentially diluted solutions were used for testing. IC50 values were calculated from the resulting sigmoidal dose-response inhibition slopes.

\subsection{Cell-based assay}

HeLa cells (American Type Culture Collection (ATCC), Rockville, MD) were plated in 96-well plates at a density of 6,000 cells per well and maintained in Minimum Essential Medium (Life Technologies, Zug, Switzerland), supplemented with $10 \%$ fetal calf serum, penicillin G (100 U/mL) and streptomycin $(100 \mu \mathrm{g} / \mathrm{mL})$ at $37{ }^{\circ} \mathrm{C}$ in a humidified atmosphere of $5 \% \mathrm{CO}_{2}$ in air, for $24 \mathrm{~h}$. Cells were then treated with test samples diluted in DMSO at six different concentrations (0.5\% DMSO in assay well) together with BOC-Ac-Lys-AMC substrate at $21.0 \mu \mathrm{M}$. The plate was then incubated at $37^{\circ} \mathrm{C}$ for $4 \mathrm{~h}$. The reaction was stopped by the addition of lysis buffer $(1 \mu \mathrm{M}$, Trichostatin $\mathrm{A}, 1 \%$, Igepal CA-630, $50 \mathrm{mM}$, Tris/Cl, $\mathrm{pH} 8.0,137 \mathrm{mM} \mathrm{NaCl}, 2.7 \mathrm{mM} \mathrm{KCl}, 1 \mathrm{mM} \mathrm{MgCl} 2$ ), trypsin was added and the experiment was finished as described above. The relative amount of deacetylated substrate was obtained by fluorescence reading $(460 / 360 \mathrm{~nm})$. Results are the mean of three independent experiments. Trichostatin A was used as positive control. 


\subsection{Molecular docking}

Molecular docking calculations were carried out with GOLD version 5.2 (CCDC Cambridge). The three-dimensional structure of HDAC2 was taken from the Protein Data Bank (PDB id: 4LXZ). From this protein, water molecules and the co-crystallized ligand were removed whereas hydrogen atoms were added using Sybyl-X 1.3 (Tripos Inc.). Ligands for docking were also prepared using Sybyl-X 1.3, checking atom and bond types together with protonation states. The active site was then defined by selecting HDAC2 residues within $6 \AA$ from the co-crystallized ligand. Trigonal bipyramid geometry for the zinc ion was defined. ChemPLP score was used for ranking the one hundred docking poses generated for each ligand. The rmsd_analysis tool of GOLD was finally used for cluster analysis within a cut-off of $2 \AA$. Images were generated with Sybyl-X 1.3 (Tripos Inc.).

\subsection{Cellular sensitivity to test compounds}

Cellular sensitivity to test compounds was evaluated by growth-inhibition assay after 72-h drug exposure. Cells in the logarithmic phase of growth were seeded in duplicate into 6-well plates. Twenty-four hours after seeding, the test compound was added to the medium. Cells were harvested $72 \mathrm{~h}$ after drug exposure and counted with a cell counter. $\mathrm{IC}_{50}$ is defined as the drug concentration causing a $50 \%$ reduction of cell number compared with that of untreated control.

\subsection{Cell cycle analysis}

The cell cycle distribution was analyzed in propidium iodide stained cells by FACScan flow cytometry (Becton Dickinson), as described previously [18].

\subsection{TUNEL assay}

Apoptosis was determined in ovarian carcinoma IGROV-1 cells by TUNEL assay following $72 \mathrm{~h}-$ exposure to the drug and fixed in $4 \%$ paraformaldehyde for $45 \mathrm{~min}$, at room temperature. The in situ cell death detection kit fluorescein (Roche, Mannheim, Germany) was used according to manufacturers' instructions. Samples were analyzed by FACScan flow cytometry (Becton Dickinson).

\subsection{Western blotting}

Cells treated with various concentrations of HDAC inhibitors for $4 \mathrm{~h}$ were collected and lysed as previously described [18]. 


\subsection{Tumor models and evaluation of antitumor activity}

The experiments were performed using female athymic Swiss nude mice. Mice were maintained in laminar flow rooms keeping temperature and humidity constant. Mice had free access to food and water. Experiments were approved by the Ethics Committee for Animal Experimentation of the Istituto Nazionale Tumori of Milan according to institutional guidelines.

Exponentially growing tumor cells $\left(10^{7}\right.$ cells/mouse) were s.c. injected into the right flank of athymic nude mice. Tumor lines were achieved by serial s.c. passages of fragments (about $2 \times 2 \times 6$ $\mathrm{mm}$ ) from growing tumors into healthy mice. Animals were treated 3 days after tumor implantation. Compounds were dissolved in DMSO and diluted in PBS containing 5\% Cremophor to a final concentration of $10 \%$ DMSO.

\section{Acknowledgments}

This work was performed within the framework of COST Actions CM1106 (Chemical Approaches to Targeting Drug Resistance in Cancer Stem Cells). The Authors are grateful to Professor Nadine Martinet for her contribution to the network coordination and for creating the compound library.

\section{References}

[1] X. Yang,. H. Han, D. D. De Carvalho, F. D. Lay, P. A. Jones, G. Liang, Cancer Cell 26 (2014) $577-590$.

[2] D. C. Hargreaves , G. R. Crabtree, Cell Research 21 (2011) 396-420.

[3] T. K. Kelly, D. D De Carvalho, P. A. Jones, Nature Biotechnology 28 (2010) 1069-1078.

[4]P. Tessarz, T. Kouzarides, Nature Reviews Molecular Cell Biology 15 (2014) 703-708.

[5] E. Verdin, M. Ott, Nature Reviews Molecular Cell Biology16 (2015)258-264.

[6] K. J. Falkenberg, R. W. Johnstone, Nat. Rev. Drug Discov. 13 (2014) 673-691.

[7] M. Mottamal, S. Zheng, T. L. Huang, G. Wang, Molecules 20 (2015) 3898-3941.

[8] S. Dallavalle, R. Cincinelli, R. Nannei, L. Merlini, G. Morini, S. Penco, C. Pisano, L. Vesci, R. Barbarino, V. Zuco, M. De Cesare, F. Zunino, Eur. J. Med. Chem. 44 (2009) 1900-1912.

[9] M.A. Rivieccio, C. Brochier, D. E. Willis, B. A. Walzer, M.A. D’Annibale, K. McLaughlin, A. Siddiq, A. P. Kozikowski, S. R. Jaffrey, J. L. Twiss, R. R. Ratan, B. Langley, Proc. Natl. Acad. Sci. 106 (2009) 19599-19604.

[10] R. Cincinelli, L. Musso, G. Giannini, V. Zuco, M. De Cesare, F. Zunino, S. Dallavalle, Eur. J. Med. Chem. 79 (2014) 251-259. 
[11] G. Giannini, T. Brunetti, R. Pezzi, G. Battistuzzi, M. Di Marzo, M. Marzi, W. Cabri, L. Vesci, C. Pisano, Bioorg. Med. Chem. Lett. 19 (2009) 2346-2350.

[12] X. Li, J. Wu, X. Li, W. Mu, X. Liu, Y. Jin, W. Xu, Y. Zhang, Bioorg. Med. Chem. 23 (2015) $6258-6270$.

[13] A. Detsi, M. Koufaki, T. Calogeropoulou, J. Org. Chem. 67 (2002) 4608-4611.

[14] V. Zwick, A-O. Chatzivasileiou, N. Deschamps, M. Roussaki, C. Simoes-Pires, A. Nurisso, I. Denis, C. Blanquart, N. Martinet, P-A. Carrupt, A. Detsi, M. Cuendet, Bioorg. Med. Chem. Lett. 24 (2014) 5497-5501.

[15] A. Chakrabarti, I. Oehme, O. Witt, G. Oliveira, W. Sippl, C. Romier, R. J. Pierce, M. Jung, Trends in Pharmacol. Sci. 36 (2015) 481-492.

[16] P. Mestichelli, M. J. Scott, W.R.J.D. Galloway, J. Selwyn, J.S. Parker, D.R. Spring Org. Lett. 15 (2013), 5448-5451.

[17] J.R. Davies, P.D. Kane, C.J. Moody, A.M. Z. Slawin J. Org. Chem. 70 (2005) 5840-5851.

[18] C. Giommarelli, V. Zuco, E. Favini, C. Pisano, F. Dal Piaz, N. De Tommasi, F. Zunino, Cell Mol. Life Sci. 67 (2010) 995-1004. 